\title{
Food Refusal: A Rare Presenting Symptom of Cotard's Syndrome
}

\author{
Gojendra Senjam, Samuel L Singson, Prabin Kumar Sahu, Asheema Haobijam
}

\section{Gojendra Senjam, Samuel L Singson, Prabin Kumar Sahu, Asheema Haobijam}

Department of Psychiatry, Regional Institute of Medical Sciences (RIMS), Imphal, Manipur, INDIA.

\section{Correspondence}

Dr. Gojendra Senjam

Associate Professor, Department of Psychiatry, Regional Institute of Medical Sciences, Imphal, Manipur, INDIA.

Phone no: +91-9862032931

Email: drgojendra@gmail.com

\section{History}

- Submission Date: 07-06-2021

- Revised Date: 24-06-2021

- Accepted Date: 10-07-2021

DOI : 10.5530/ijmedph.2021.4.40

Article Available online

http://www.ijmedph.org/v11/i4

\section{Copyright}

(C) 2021 Phcog.Net. This is an openaccess article distributed under the terms of the Creative Commons Attribution 4.0 International license.

\section{ABSTRACT}

Cotard's syndrome is a rare neuropsychiatric condition characterised by extreme delusion of nihilism or negation towards self. It is mostly associated with psychiatric conditions like major depressive disorder, schizophrenia as well as some organic brain conditions like brain injury, stroke, Parkinson's disease, multiple sclerosis etc. Of the innumerable types of presentations of this condition, food refusal is a rare type and hence we report this case as such.

Key words: Cotards's syndrome, Delusion, Guilt, Food refusal, Rare.

\section{INTRODUCTION}

Cotard's syndrome, named after the French doctor Dr. Jules Cotard, who described the first known case in 1880,is a neuropsychiatric condition mostly seen in patients suffering from severe depression, schizophrenia, bipolar disorder and in a few organic conditions like dementia, epilepsy, parkinson's disease, brain injury, migraine, cerebral tumors, etc. initially described as anxious melancholia or the delusion of negation, it was termed Cotard's syndrome by Emil Regis in 1893 and the term was popularized by Jules Seglas. It is characterized by anxious melancholia, delusion of non-existence concerning one's own body to the extent of delusions of immortality. ${ }^{1,2}$ Here we present a case of a young man who presented to the hospital as he refused to take food believing that his intestine along with his anal opening were mostly absent or defunct.

\section{CASE REPORT}

Mr A, a 24- year old Christian graduate student who had no premorbid mental illness and had a history of occasional cannabis use was brought to the psychiatric OPD as he was refusing to take food and defecating for a period of 3 months. He told that he had been noticing altered stool compare to before because of the fact that he had little or no intestines left inside his abdomen and whatever of it was left wasn't working appropriately to digest his food. He also believed that his anal opening was not working as it should after he had inserted some foreign objects inside it about 4-5 times during the above said period. He used to insert objects like carrots or his fingers through his anus in order to achieve sexual gratification after watching online porn. He believed that he had brought this curse upon himself as he had done some blasphemous things and god was punishing him for such indecent acts and he indeed deserved this punishment. Since his intestines were rendered useless, he could not eat or defecate anymore as eating food would accumulate in the hollow of his abdomen and may lead to unnecessary adversity. For the past few weeks he was also feeling low, was withdrawn from family and friends, had sleeping difficulties on and off along with feelings of guilt and repentance, although he never had at any point of time considered killing himself. He had no other medical comorbidities and had no history suggesting of mental illness in his family. A complete physical and neurological examination did not reveal any abnormality. His routine blood investigations were within normal range. Thyroid and lipid tests revealed no aberrations. ecg, usg were all normal. MSE revealed a sad and restricted affect, expressed hopelessness and worthlessness, suffered from delusions of guilt and nihilism and had a poor insight into his illness.

\section{MANAGEMENT}

He was started on tab. Sertraline $50 \mathrm{mg}$ once daily and tab. Risperidone $4 \mathrm{mg}$ in two divided doses. He was initially sceptic about taking medications but agreed after much persuasion. After approx. 3 weeks on regular medications he said he was feeling better and had started taking food regularly and his bowel habits were improved but he was still worried about portions of his missing intestine and asked to be referred to surgery department in case any operation was required to make his bowels functional again.

\section{DISCUSSION}

Cotard formulated his first case, that of a 43- year old woman as a new type of depression characterized by the following symptoms: anxious melancholia, ideas of damnation or rejection, insensitivity to pain, delusions of non-existence concerning one's own body, and delusions of immortality. Cotard categorized it as lypémanie, a kind of psychotic depression. In 1882, Cotard introduced délire des négations as 
new terminology for the syndrome. The most prominent symptoms of Cotard's syndrome are depressive mood (89\%), nihilistic delusions concerning one's own body (86\%), nihilistic delusions concerning one's own existence (69\%), anxiety (65\%), delusions of guilt (63\%), delusions of immortality (55\%), and hypochondriac delusions (58\%). ${ }^{3}$ Usually conceived as an extreme case of depression, hypochondria, or psychosis, the condition is quite rare. Cotard himself tried to explain it by focusing on its distinction from classical persecutory delusions and suggesting that it could be a kind of reversed grandiosity. He proposed a psychosensory basis where there is general psychomotor impairment of volition. Some authors highlighted a disorder of the bodily self, and a few recent theories postulated an impairment of right hemispheric functions, leading to perceptual and somatosensory feelings of unreality, which when added to reasoning impairment gave a dysfunctional attributional style. ${ }^{4}$ Currently, Cotard's Syndrome is not classified as an isolated disorder in the Diagnostic and Statistical Manual of Mental Disorders (DSM-5) of the American Psychiatric Association or in the International Statistical Classification of Diseases and Related Health Problems (ICD-10). There is though demand to consider it as secondary syndrome in cases of unipolar depression, bipolar depression and primary psychotic disorders. ${ }^{5}$ Though this condition is quite commonly found in psychiatric settings but it may be present in other neurological diseases like Parkinson's disease, migraine, brain tumors, traumatic brain injury, arterio-venous malformations, and multiple sclerosis as well as neurosyphilis, stroke, and viral encephalitis. Understanding cotard's syndrome requires an unravelling of both of its psychiatric and neurological underpinnings. ${ }^{6-9}$ Our case is one example of one of the many varieties and diversities of the symptomatic presentation of this rare syndrome.

\section{ACKNOWLEDGEMENT}

We sincerely thank Prof. R.K. Lenin Singh, Head of Department, Department of Psychiatry, Regional Institute of Medical Sciences (RIMS),
Imphal for his guidance and support during the preparation of this manuscript.

\section{CONFLICT OF INTEREST}

The authors declare that there is no conflict of interest.

\section{REFERENCES}

1. Huarcaya-Victoria J, Ledesma-Gastañadui M, Huete-Cordova M. Cotard's syndrome in a patient with schizophrenia: case report and review of the literature. Case Rep Psychiatry. 2016;2016:6968409. doi: 10.1155/2016/6968409, PMID 28053798.

2. Grover S, Aneja J, Mahajan S, Varma S. Cotard's syndrome: two case reports and a brief review of literature. J Neurosci Rural Pract. 2014;5(Suppl 1);Suppl 1:S59-62. doi: 10.4103/0976-3147.145206, PMID 25540544.

3. Debruyne H, Portzky M, Van den Eynde F, Audenaert K. Cotard's syndrome: a review. Curr Psychiatry Rep. 2009;11(3):197-202. doi: 10.1007/s11920-0090031-z, PMID 19470281.

4. Dieguez S. Cotard syndrome Neurologic-Psychiatric Syndromes in Focus-Part II. Front Neurol Neurosci. 2018;42. doi: 10.1159/000475679, PMID 29151088.

5. Moschopoulos NP, Kaprinis S, Nimatoudis J. Cotard's syndrome: case report and a brief review of literature. Psychiatriki. 2016;27(4):296-302. doi: 10.22365/ jpsych.2016.274.296, PMID 28114093

6. Ramirez-Bermudez J, Aguilar-Venegas LC, Crail-Melendez D, Espinola-Nadurille M, Nente F, Mendez MF. Cotard syndrome in neurological and psychiatric patients. J Neuropsychiatry Clin Neurosci. 2010;22(4):409-16. doi: 10.1176/ jnp.2010.22.4.409, PMID 21037126

7. Factor SA, Molho ES. Threatening auditory hallucinations and Cotard syndrome in Parkinson disease. Clin Neuropharmacol. 2004;27(5):205-7. doi: 10.1097/01. wnf.0000144040.20600.c1, PMID 15602098.

8. Young AW, Robertson IH, Hellawell DJ, De Pauw KW, Pentland B. Cotard delusion after brain injury. Psychol Med. 1992;22(3):799-804. doi: 10.1017/ s003329170003823x, PMID 1410102

9. Dieguez, S., Assal, G. and Bogousslavsky, J., 2007. Visconti and Fellini: from left social neorealism to right-hemisphere stroke. In Neurological Disorders in Famous Artists-Part 2(Vol. 22, pp. 44-74). Karger Publishers. 